
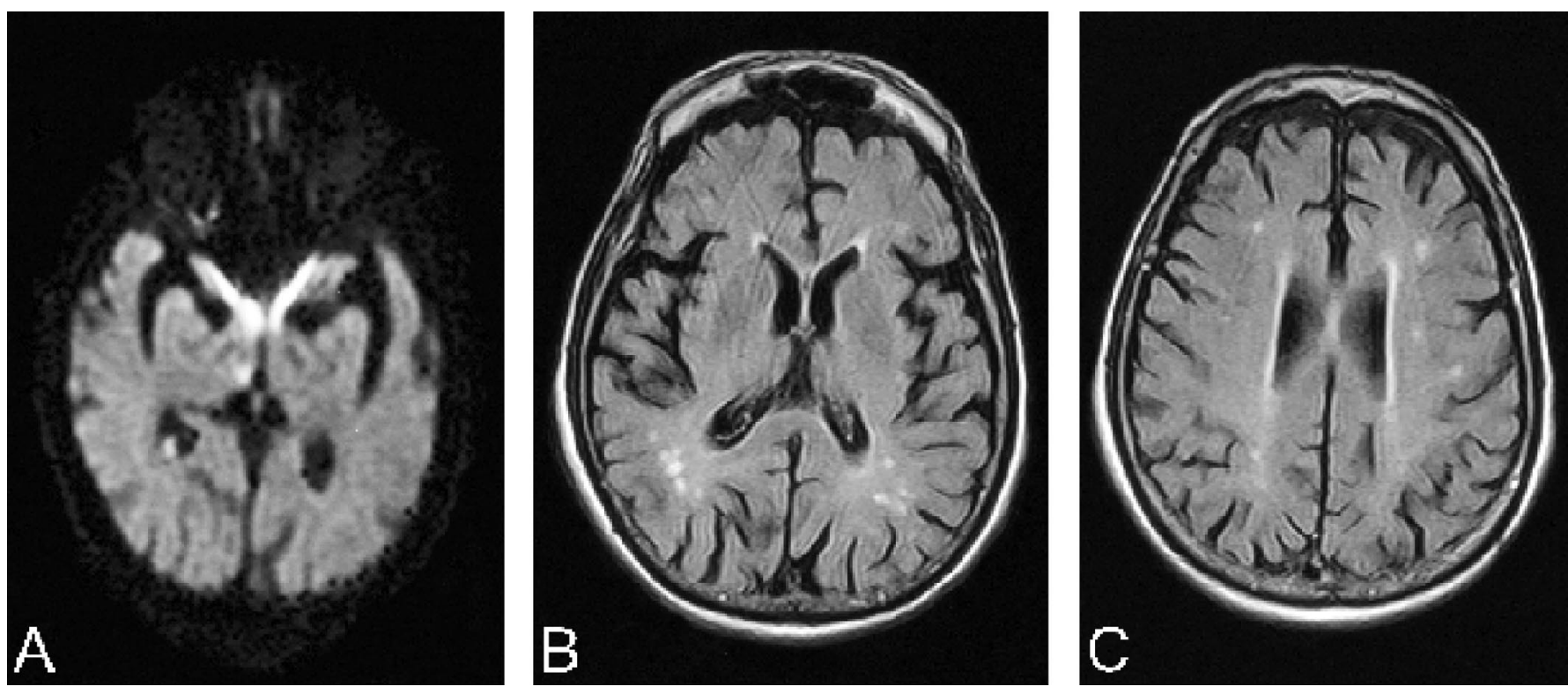

Figure. Diffusion-weighted sequence (A) showing an acute right posteromedial thalamic infarction. fluid-attenuated inversion recovery (B and $C$ ) sequences disclosing additional subcortical lesions that did not exhibit restricted diffusion and therefore were unlikely to be acute.

\section{VIDEo Cardiac saddle embolus}

Sylvia M. Zuniga, MD; and Alejandro A. Rabinstein, MD, Miami, FL

A 74-year-old man with a history of hypertension and recent multiple abdominal surgeries presented with transient vertical diplopia, left-sided weakness, and persistent left-side numbness. Examination of eye movements and motor system was normal, but he had left hypoesthesia. MRI showed acute right posteromedial thalamic infarction (figure, A). Magnetic resonance angiograms of brain and neck did not reveal any significant vascular disease. Transthoracic echocardiogram revealed a large intracardiac thrombus. Lower extremity duplex disclosed thrombosis of the right femoral and popliteal veins. The patient was taken to the

Address correspondence and reprint requests to Dr. Alejandro A. Rabinstein, 1150 MW 14th street, Suite 304, Miami, FL 33101; e-mail: arabinstein@med.miami.edu operating room for removal of the thrombus, confirmed with intraoperative transesophageal echocardiogram (video), but no thrombus was found upon opening the heart. Intraoperative abdominal angiogram revealed thrombosis of the left superior and inferior mesenteric and left renal arteries, indicating that the thrombus had likely fragmented in multiple emboli (figure, B and C). Despite emergent mesenteric artery thrombectomy and partial bowel resection, the patient died from the complications of extensive intestinal ischemia.

We believe this patient's small subcortical infarct was due to embolism to a branch of the right posterior cerebral artery, perhaps the thalamic-subthalamic artery. This case illustrates that even life-threatening sources of embolism can present with small subcortical strokes. ${ }^{1}$

1. Gan R, Sacco RL, Kargman DE, Roberts JK, Boden-Albala B, Gu Q. Testing the validity of the lacunar hypothesis: the Northern Manhattan Stroke Study experience. Neurology 1997;48:1204-1211. 


\title{
Neurology
}

\author{
Cardiac saddle embolus \\ Sylvia M. Zuniga and Alejandro A. Rabinstein \\ Neurology 2005;65;E1 \\ DOI 10.1212/01.wn1.0000173359.07603.91
}

This information is current as of July 11, 2005

\section{Updated Information \&} Services

Supplementary Material

References

Permissions \& Licensing

Reprints including high resolution figures, can be found at:

http://n.neurology.org/content/65/1/E1.full

Supplementary material can be found at:

http://n.neurology.org/content/suppl/2007/04/02/65.1.E1.DC2

http://n.neurology.org/content/suppl/2005/07/08/65.1.E1.DC1

This article cites 1 articles, 1 of which you can access for free at: http://n.neurology.org/content/65/1/E1.full\#ref-list-1

Information about reproducing this article in parts (figures,tables) or in its entirety can be found online at:

http://www.neurology.org/about/about_the_journal\#permissions

Information about ordering reprints can be found online:

http://n.neurology.org/subscribers/advertise

Neurology ${ }^{\circledR}$ is the official journal of the American Academy of Neurology. Published continuously since 1951, it is now a weekly with 48 issues per year. Copyright . All rights reserved. Print ISSN: 0028-3878. Online ISSN: 1526-632X.

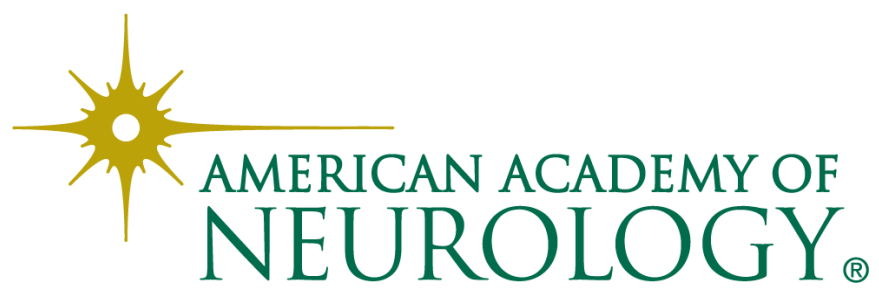

